\title{
Blood serum amino acid pool violation of in patients with liver cirrhosis
}

\author{
O. P. Balazh \\ Uzhgorod National University

\section{Порушення амінокислотного пулу сироватки крові у хворих із цирозом печінки}

\author{
О. П. Балаж
}

Ужгородський національний університет

\begin{abstract}
Objective. To investigate serum amino acid pool changes in patients with liver cirrhosis.

Materials and methods. 95 patients with liver cirrhosis were participated in the study. In the 1st group (class A disease severity according to Child- Pugh score) there were 18 (18.95\%) patients, in the 2 nd group (class B) - 25 (26.3\%), in the 3rd groups (class C) $-52(54.7 \%)$ patients. The amount of free amino acids in blood serum was determined by reversed-phase high-performance liquid chromatography in isocratic elution mode with electrochemical detection.

Results. Violations of free amino acid reserves were revealed in patients with cirrhosis of the liver with a predominant accumulation of aromatic amino acids: phenylalanine - $(162.45 \pm 14.12) \mathrm{nmol} / \mathrm{ml}$, tyrosine $-(99.05 \pm 10.07) \mathrm{nmol} / \mathrm{ml}$, tryptophan $-(76.10 \pm 12.40) \mathrm{nmol} / \mathrm{ml}$, as well as an increase in the content of proline, lysine, cysteine $(\mathrm{p}<0.05)$. In parallel, the decreasing of free serum amino acids with branched side chain levels were observed: valine $-\operatorname{up}(150.10 \pm 8.92) \mathrm{nmol} / \mathrm{ml}$ leucine - up $(75.14 \pm 5.12) \mathrm{nmol} / \mathrm{ml}(\mathrm{p}<0.05)$ and isoleucine - up to $(80.40 \pm 8.01) \mathrm{nmol} / \mathrm{ml}$.

Conclusions. The correlation between the second degree of thick guts dysbiosis and increased levels of tryptophan was determined $(\mathrm{r}=0.77 ; \mathrm{p}<0.01)$. III degree thick dysbiosis was correlated with increasing levels of phenylalanine $(\mathrm{r}=0.71 ; \mathrm{p}$ $<0.01)$. In patients of 2 nd group the correlations between levels of tryptophan and II degree of intestinal dysbiosis $(r=0.58 ; p$ $<0.01)$ and the levels of tyrosine in phenylalanine in III stage intestinal dysbiosis were detected.

Keywords: liver cirrhosis; amino acid pool; intestinal dysbiosis.

Реферат

Мета. Дослідити зміни амінокислотного пулу сироватки крові у хворих із цирозом печінки.

Матеріали і методи. У дослідженні взяли участь 95 хворих із цирозом печінки. У 1-й групі (клас А тяжкості захворювання за Child-pugh) було 18 (18,95\%) хворих, у 2-й групі (клас В) - 25 (26,3\%), у 3-й групі (клас С) - 52 (54,7\%) хворих. Кількість вільних амінокислот у сироватці крові визначали за методом обернено-фазової високоефективної рідинної хроматографії в ізократичному режимі елюювання з електрохімічним детектуванням.

Результати. У хворих із цирозом печінки виявили порушення резервів вільних амінокислот з переважним накопиченням ароматичних амінокислот: фенілаланіну - $(162,45 \pm 14,12)$ нмоль/мл, тирозину - $(99,05 \pm 10,07)$ нмоль/мл, триптофану - $(76,10 \pm 12,40)$ нмоль/мл, а також збільшення вмісту проліну, лізину, цистеїну (p<0,05). Паралельно 3 цим спостерігали зниження рівнів вільних амінокислот сироватки крові з розгалуженим бічним ланцюгом: валіну - до (150,10 $\pm 8,92)$ нмоль/мл, лейцину - до $(75,14 \pm 5,12)$ нмоль/мл $(\mathrm{p}<0,05)$ та ізолейцину - до $(80,40 \pm 8,01)$ нмоль/мл.

Висновки. Встановлено залежність між II ступенем дисбіозу товстої кишки та збільшенням рівнів триптофану (r=0,77; $\mathrm{p}<0,01)$. Дисбіоз товстої кишки ІІІ ступеня корелював із збільшенням рівнів фенілаланіну $(\mathrm{r}=0,71 ; \mathrm{p}<0,01)$. У пацієнтів 2-ї групи, зокрема, встановлена залежність між рівнями триптофану і II ступенем дисбіозу кишечника $(\mathrm{r}=0,58 ; \mathrm{p}<0,01)$ та рівнями тирозину і фенілаланіну і ІІІ ступенем дисбіозу кишечника.
\end{abstract}

ключові слова: цироз печінки; амінокислотний пул; дисбіоз кишечника.

Today, one of the most pressing problems of Hepatology is timely diagnosis and treatment of chronic hepatic diseases [1, 2]. Among gastroenterological diseases, therapists, gastroenterologists and surgeons most often face hepatic cirrhosis (HC) and its complications [3, 4].

Despite the variety of etiological factors (viral, alcoholic, toxic, etc.), structural and functional hepatic disorders are very similar, so their progression usually ends with the formation of HC and hepatic failure. The latter are difficult not only to diagnose, but also to treat, and since the liver plays a leading role in metabolic processes, its injury affects the function of other organs [3 - 5].

The main reactions of amino acid transmutation (AA) in the liver are their mutual transmutation, breaking of the carbohydrate skeleton with the release of energy, and provision of gluconeogenesis by transamination and oxidative deamination reactions. Among the mechanisms of maintaining of balance between representatives of "harmful" and "beneficial" AA in patients with HC, urea biosynthesis is crucial, which occurs entirely in the hepatic Krebs Cycle [6, 7]. 
Disturbance of the colonic detoxification function contributes to an increase in the levels of nitrogen-containing AA in the body, which, bypassing the portal system, directly enter the brain cells and contribute to the development of clinical signs of hepatic encephalopathy (HE) [5,6]. In the treatment of patients with $\mathrm{HC}$, one of the central places is occupied by treatment and prevention of the disease complications, in particular HE, which occurs as a result of deep metabolic disorders [8].

With various biochemical and functional changes in patients with $\mathrm{HC}$ in combination with cytotoxic effect of metabolic products on neurons and glia cells of the brain, the pathology of cerebral circulation should be assessed as conventional one in $\mathrm{HE}$.

Timely detection of disorder of ratio of the blood serum AA levels against the background of examination of the colonic microbial composition and their correction are important primarily in treatment of patients with HC in order to prevent the HE signs development [9, 10].

Objective of the investigation was: to study the changes in the blood serum amino acid pool in patients with HC.

\section{Materials and methods}

The study involved 95 patients with HC, who underwent inpatient treatment in 2018-2020 yrs in the Department of Anesthesiology-Critical Care, Surgical and Gastroenterological departments of the Andrii Novak Zakarpattia Region Clinical Hospital (Uzhhorod) The criteria for excluding patients from the study were HC of viral etiology, primary biliary cirrhosis, hepatic cancer, and Budd-Chiari syndrome. The age of the examined patients ranged from 28 to 65 yrs old, the average age was $(42.1 \pm 6.8)$ yrs old. The control group consisted of 15 apparently healthy people aged 26 - 59 yrs olds, whose average age was (42.2 \pm 3.4 ) yrs old. There were 9 men (60.0\%) and 6 women (40.0\%). Patients with $\mathrm{HC}$ were divided into groups according to the disease severity classes and based on to the Child-Pugh classification. Group 1 (Class A - compensation stage) have included 18 (18.95\%) patients, Group 2 (Class B - subcompensation stage) - 25 (26.3\%), and group 3 (Class C - decompensation stage) $-52(54.7 \%)$ patients.

The amount of free AA in the blood serum was determined by reverse-phase high-value liquid chromatography in an isocratic elution mode with electrochemical detection [1-3].

Method for obtaining of the AA derivatives: to convert the studied compounds into derivatives, $25 \mu$ of a standard AA mixture, $15 \mu$ of reagent (ortho-phthalic anhydride +2 -mercaptoethanol) and $160 \mu \mathrm{l}$ of $0.1 \mathrm{~m}$ sodium tetraborate solution were mixed in a micro-sampling tube for $3 \mathrm{~min}, 20 \mu \mathrm{l}$ of the mixture was injected into a chromatographic column.

To obtain derivatives with the Ortho-phthalic anhydride/ sodium sulfate reagent, $40 \mu \mathrm{l}$ of the standard AA mixture, 10 $\mu l$ of the Ortho-phthalic anhydride/sodium sulfate reagent, and $150 \mu$ l of borate buffer were mixed in a micro-sampling tube for $25 \mathrm{~min}$. $10 \mu \mathrm{l}$ of the mixture was injected into a chromatographic column.
For the protein deposit purposes, $100 \mu$ l of the blood serum and $400 \mu \mathrm{l}$ of methanol were mixed in micro-sampling tubes. The sample was centrifuged for $5 \mathrm{~min}$ at 10,000 revolutions. The deposit was discarded, and the supernatant fluid, containing free AA, preserved. To convert AA, contained in the blood serum, into derivatives $20 \mu \mathrm{l}$ of supernatant fluid, $30 \mu \mathrm{l}$ of the corresponding reagent and $150 \mu \mathrm{l}$ of 0.1 $\mathrm{M}$ sodium tetraborate solution were mixed, and $10 \mu \mathrm{l}$ of the mixture was injected into a chromatographic column.

A liquid chromatograph (Milichrom, Russia) with an electrochemical detector was used for Chromatography. The electrode potential was +0.75 and $+0.85 \mathrm{~V}$. The metal column $(250 \times 4.0 \mathrm{~mm})$ was filled with Spherisorb ODS sorbent with a grain size of 5 microns. The mobile phase have contained $18 \mathrm{Vol}$ \% of methanol, $0.01 \mathrm{M}$ of sodium hydrophosphate, $0.01 \mathrm{M}$ of sodium dihydrogen phosphate, and $0.002 \mathrm{M}$ of EDTA (pH 7.0). The correlation coefficient was determined, using the Pearson paired method to identify relationships between the obtained indicators in the Jamovi 1.6.14 program.

\section{Results}

In patients with $\mathrm{HC}$, against the background of changes in the quantitative and qualitative composition of colonic bacterial population, as well as the ratio distortion of free AA reserves in the blood serum were observed.

When studying the amino acid pool in patients with HC, a ratio distortion of the free AA reserves with a predominant accumulation of aromatic amino acids was found: phenylalanine - up to $(162.45 \pm 14.12) \mathrm{nmol} / \mathrm{ml}$, tyrosine - up to $(99.05 \pm 10.07) \mathrm{nmol} / \mathrm{ml}$, tryptophan - up to $(76.10 \pm 12.40)$ $\mathrm{nmol} / \mathrm{ml}$, an increase in the proline content to $(244.00 \pm$ $30.01) \mathrm{nmol} / \mathrm{ml}$, lysine - up to $(379.12 \pm 25.41) \mathrm{nmol} / \mathrm{ml}$, cysteine - up to $(234.77 \pm 23.56) \mathrm{nmol} / \mathrm{ml}(\mathrm{P}<0.05)$, and methionine - up to $(35.55 \pm 4.57) \mathrm{nmol} / \mathrm{ml}$.

In parallel, a decrease in the levels of free AA in the blood serum with branched side chain was observed: valine - up to $(150.10 \pm 8.92) \mathrm{nmol} / \mathrm{ml}$, leucine - up to $(75.14 \pm 5.12)$ $\mathrm{nmol} / \mathrm{ml}(\mathrm{P}<0.05)$ and isoleucine - up to $(80.40 \pm 8.01)$ $\mathrm{nmol} / \mathrm{ml}$. There was also a statistically significant decrease in the content of serine - up to $(83.66 \pm 5.71) \mathrm{nmol} / \mathrm{ml}$, glutamine - up to $(476.20 \pm 44.00) \mathrm{nmol} / \mathrm{ml}$, alanine - up to $(324.77 \pm 23.25) \mathrm{nmol} / \mathrm{ml}(\mathrm{P}<0.05)$ and histidine, arginine, asparagine, glycine, threonine $(\mathrm{p}>0.05)$ in the blood serum.

These changes are explained by a pronounced decrease in individual AA degradation, their inclusion in protein biosynthesis in tissues, especially in albumin synthesis in hepatic tissues, as well as a decrease in the role of arginine in the urine formation in patients with HC.

The most pronounced changes in the amino acid pool of the blood were found in patients of the 2 nd and 3 rd groups, namely, a predominant decrease in the content of AA with a branched side chain, which has a positive effect on the human organism (Table. 1 ).

The lowest levels of valine, leucine, and isoleucine were recorded in patients of Group 3: (137.77 \pm 10.52$) \mathrm{nmol} / \mathrm{ml}$, 
Table 1. Reserves of free AA of blood serum in patients with HC

\begin{tabular}{|c|c|c|c|}
\hline \multirow[b]{2}{*}{ Amino acid, $\mathrm{nmol} / \mathrm{ml}$} & \multicolumn{3}{|c|}{ Group of patients with $\mathrm{HC}$} \\
\hline & $\begin{array}{c}1 \mathrm{st} \\
(\mathrm{n}=18)\end{array}$ & $\begin{array}{c}2 \mathrm{nd} \\
(\mathrm{n}=25)\end{array}$ & $\begin{array}{c}3 \mathrm{~d} \\
(\mathrm{n}=52)\end{array}$ \\
\hline Ornithine & $225.30 \pm 21.41$ & $200.05 \pm 17.50$ & $199.27 \pm 9.15^{*}$ \\
\hline Lysine & $351.41 \pm 33.15$ & $389.21 \pm 30.6^{*}$ & $393.15 \pm 34.5^{*}$ \\
\hline Cysteine & $232.11 \pm 28.72$ & $257.12 \pm 12.15$ & $261.45 \pm 15.1^{*}$ \\
\hline Histidine & $78.20 \pm 4.41$ & $60.01 \pm 5.52 *$ & $57.11 \pm 3.12 *$ \\
\hline Arginine & $73.22 \pm 4.47$ & $70.11 \pm 5.52$ & $69.26 \pm 11.10$ \\
\hline Asparagine & $7.36 \pm 1.45$ & $6.92 \pm 0.12$ & $6.85 \pm 0.98$ \\
\hline Serine & $80.50 \pm 9.25$ & $85.00 \pm 4.40$ & $80.12 \pm 9.20$ \\
\hline Glycine & $252.10 \pm 12.14$ & $231.50 \pm 15.00$ & $228.00 \pm 15.75$ \\
\hline Glutamine & $500.36 \pm 25.10$ & $462.10 \pm 32.5^{*}$ & $458.20 \pm 25.5^{*}$ \\
\hline Threonine & $152.41 \pm 9.15$ & $114.50 \pm 3.51^{*}$ & $111.26 \pm 8.85^{*}$ \\
\hline Alanine & $333.15 \pm 19.82$ & $311.00 \pm 10.10$ & $309.11 \pm 7.75$ \\
\hline Proline & $232.10 \pm 41.15$ & $266.17 \pm 25.0 *$ & $271.10 \pm 15.4^{*}$ \\
\hline Tyrosine & $90.00 \pm 7.04$ & $108.13 \pm 5.56^{*}$ & $112.00 \pm 7.75^{*}$ \\
\hline Tryptophan & $69.00 \pm 7.70$ & $91.15 \pm 4.41^{*}$ & $93.15 \pm 6.50^{*}$ \\
\hline Methionine & $33.44 \pm 7.23$ & $40.25 \pm 5.12 *$ & $40.41 \pm 7.77^{*}$ \\
\hline Valine & $144.00 \pm 9.25$ & $139.45 \pm 23.74$ & $137.77 \pm 10.52$ \\
\hline Phenylalanine & $155.50 \pm 18.12$ & $178.44 \pm 20.20$ & $180.11 \pm 32.15$ \\
\hline Leucine & $80.80 \pm 14.99$ & $63.70 \pm 15.41^{*}$ & $61.00 \pm 10.5^{*}$ \\
\hline Isoleucine & $83.26 \pm 7.41$ & $78.02 \pm 4.04$ & $77.10 \pm 15.44$ \\
\hline
\end{tabular}

$(61.00 \pm 10.5) \mathrm{nmol} / \mathrm{ml}$, and $(77.10 \pm 15.44) \mathrm{nmol} / \mathrm{ml}$, respectively, and in patients of the Group 2: (139.45 \pm 23.74 $\mathrm{nmol} / \mathrm{ml},(63.70 \pm 15.41) \mathrm{nmol} / \mathrm{ml}$, and $(78.02 \pm 4.04) \mathrm{nmol} /$ $\mathrm{ml}$, respectively. These changes were accompanied by an increase in the levels of phenylalanine, tyrosine and tryptophan with maximum values in patients of the $3 \mathrm{rd}$ Group - up to $(180.11 \pm 32.15) \mathrm{nmol} / \mathrm{ml},(112.00 \pm 7.75) \mathrm{nmol} /$ $\mathrm{ml}$, and $(93.15 \pm 6.50) \mathrm{nmol} / \mathrm{ml}$, respectively. The processes of the AA metabolism were the least affected in patients of the 1st group, but it was also possible to trace the above pattern in them, that is, a decrease in the levels of AA with a branched side chain and an increase in the levels of aromatic AA, which have a toxic effect on the patients, suffering $\mathrm{HC}$, resulting through various mechanisms to formation of the HE clinical manifestations.

The decrease in the AA levels with a branched side chain is explained by their increased destruction in the muscle and adipose tissues. The clinical reflection of this phenomena were characteristic changes in the patients' nutritional status: a decrease in the muscle mass and a decrease in adipose tissue, typical for HC hypotrophy of the rotator cuff, thinning of the skin, injury to the mucous membranes, hypoalbuminemia.

After performing a correlation analysis, we have found a relationship between the II and III degrees of colonic dysbiosis and an increase in the levels of predominantly aromatic AA in the blood serum (tryptophan, tyrosine, and phenylalanine) in patients with HC (Table. 2).

Having studied the relationship between the pronouncement of the amino acid imbalance and dysbiotic disorders in patients with HC of different groups, the corresponding rela-
Table 2. Relationship between serum AA content values and the pronouncement of colon dysbiotic disorders in patients with $\mathrm{HC}$

\begin{tabular}{|l|c|c|}
\hline \multirow{2}{*}{ Amino acid } & \multicolumn{2}{|c|}{ Degree of colon dysbiosis } \\
\cline { 2 - 3 } & II & III \\
\hline Tryptophan & $\mathrm{r}=0.77 ; \mathrm{p}<0.01$ & - \\
\hline Tyrosine & - & $\mathrm{r}=0.51 ; \mathrm{p}<0.02$ \\
\hline Phenylalanine & - & $\mathrm{r}=0.77 ; \mathrm{p}<0.01$ \\
\hline
\end{tabular}

tionship was traced only in patients of groups 2 and 3. Both in patients with $\mathrm{HC}$ in general and in patients of Group 2 in particular, the relationship was established between the level of tryptophan and Grade II and the levels of tyrosine and phenylalanine and Grade III of colonic dysbiosis. In patients of Group 3, there was an identical relationship between the tryptophan and tyrosine levels and dysbiotic disorders, and a characteristic inverse correlation was found between phenylalanine levels and Grade II dysbiosis (Table. 3).

\section{Discussion}

Hhuman organism has two main detoxification organs - the liver, which protects the body through oxidative reactions, and the alimentary tract, whose bacterial population uses hydrolytic recovery processes for detoxification. The disruption of the interaction of these systems leads to mutual functional and structural changes in them and in the organism as a whole. Therefore, a liver-intestinal cycle of various organic and inorganic compounds can be attributed without exaggeration to the main homeostatic mechanisms [1-3]. 
Table 3. Relationship between serum AA content values and the pronouncement of dysbiotic disorders in patients with $\mathrm{HC}$ of Groups 2 and 3

\begin{tabular}{|l|c|c|c|c|}
\hline \multirow{2}{*}{ Amino acid } & \multicolumn{2}{|c|}{ Degree of colon dysbiosis in patients of Group 2 } & \multicolumn{2}{c|}{ Degree of colon dysbiosis in patients of Group 3 } \\
\cline { 2 - 5 } & II & III & II & III \\
\hline Tryptophan & $\mathrm{r}=0.58 ; \mathrm{p}<0.01$ & - & $\mathrm{r}=0.55 ; \mathrm{p}<0.02$ & - \\
\hline Tyrosine & - & $\mathrm{r}=0.43 ; \mathrm{p}<0.0 .61 ; \mathrm{p}<0.05$ & $\mathrm{r}=-0.77 ; \mathrm{p}<0.02$ & $\mathrm{r}=0.56 ; \mathrm{p}<0.02$ \\
\hline Phenylalanine & - & & - \\
\hline
\end{tabular}

Patients with HC and portal hypertension due to dysperistalsis, slowing of the rate of oro-caecal transit, hyperemia due to stasis in the intestinal wall are prone to developing a bacterial overgrowth syndrome [4, 8, 9].

Reducing the ability of the immune protection leads to destruction of links in the protective mucus barrier and an increase in the intestinal wall permeability for microbes and their components $[5,10]$.

Consequently, intestinal dysbiosis develops in parallel with the imbalance of the serum AA and is primarily manifested by an increase in the content of their aromatic representatives.

\section{Conclusions}

1. A relationship was established between the second degree of colonic dysbiosis and an increase in tryptophan levels ( $\mathrm{r}=0.77$; $\mathrm{p}<0.01)$ of the blood serum. Grade III colonic dysbiosis have correlated with the increased phenylalanine levels $(\mathrm{r}=0.71 ; \mathrm{p}<0.01)$.

2. A relationship between the levels of tryptophan and the second degree of colonic dysbiosis $(r=0.58 ; \mathrm{p}<0.01)$ and between the levels of tyrosine and phenylalanine and the third degree of colonic dysbiosis was established in patients with $\mathrm{HC}$ in general and in patients of Group 2 in particular.

Financing. The authors ensure that they do not receive any rewards in any form that may affect the results of their work.

Contribution of each autbor. Rusyn A. V. - idea, supervision over the research process; Bedei N. V. - statistical analysis; Petrychko O. I. - analysis of science-focused literature, errors correction; Balazh O. P. - creating the article style, design in accordance with the requirements of the editorial board.

Conflict of interest. The authors claim that there is no conflict of interest when performing scientific research and preparing this article.

\section{References}

1. Chen Y, Guo J, Qian G, Fang D, Shi D, Guo L, Li L. Gut dysbiosis in acute-on-chronic liver failure and its predictive value for mortality. J Gastroenterol Hepatol. 2015 Sep;30(9):1429-37. doi: 10.1111/jgh.12932. PMID: 25711972.

2. Bajaj JS, Sikaroodi M, Shamsaddini A, Henseler Z, Santiago-Rodriguez $\mathrm{T}$, Acharya $\mathrm{C}$, et al. Interaction of bacterial metagenome and virome in patients with cirrhosis and hepatic encephalopathy. Gut. 2020 Sep 30:gutjnl-2020-322470. doi: 10.1136/gutjnl-2020-322470. Epub ahead of print. PMID: 32998876.

3. Bataller R, Brenner DA. Liver fibrosis. J Clin Invest. 2005 Feb;115(2):209-18. doi: 10.1172/JCI24282. Erratum in: J Clin Invest. 2005 Apr;115(4):1100. PMID: 15690074; PMCID: PMC546435.

4. Orloff MJ, Bell RH Jr, Orloff MS, Hardison WG, Greenburg AG. Prospective randomized trial of emergency portacaval shunt and emergency medical therapy in unselected cirrhotic patients with bleeding varices. Hepatology. 1994 Oct;20(4 Pt 1):863-72. doi: 10.1002/hep.1840200414. PMID: 7927227.

5. Albillos A, Lario M, Álvarez-Mon M. Cirrhosis-associated immune dysfunction: distinctive features and clinical relevance. J Hepatol. 2014 Dec;61(6):1385-96. doi: 10.1016/j.jhep.2014.08.010. Epub 2014 Aug 15. PMID: 25135860.

6. Nedashkivskyi SM. Drug-induced liver damage:principles of diagnosis, pathological changes and treatment approaches. Emergency Medicine. 2019;(2):63-70. Ukrainian. DOI: 10.22141/22240586.2.97.2019.161644.

7. Meldekhanov TT, Imanbekova JA, Kuttybaev AD, Terlikbaeva GA. Hpatic encephalopathy: cognitive dysfunction, clinical manifestations, pathogenesis, pathophysiological principles of therapy. Vestnik KazNMU. 2019;(1):261-6. Kazakh.

8. Dam-Larsen S, Franzmann M, Christoffersen P, Larsen K, Becker U, Bendtsen F. Histology and prognosis in fatty liver patients. J Hepatol.2004;40(Suppl 1):170. doi:10.1016/S0168-8278(04)90581-8.

9. Rusyn VI, Sirchak EU, Koval GM, Malyar-Gazda NM, Petrychko OI. Hepatic encephalopathy in patients with liver cirrhosis. Kharkiv: Golden Pages; 2015. 165 p. Ukrainian. ISBN 978-966-400-328-2.

10. Sirchak YeS, Griga VI, Pichkar YoI, Gema-Bagina NM. Correction of Colon Dysbiosis in Patients with Non-Alcoholic Fatty Liver Disease and Type 2 Diabetes Mellitus. Ukr J Med Biol Sport. 2019;4(5):186-91. Ukrainian. doi: 10.26693/jmbs04.05.186. 